\title{
Project Contract Management And a Theory of ORGANIZATION
}

\section{PROFESSOR J. RODNEY TURNER}

\begin{tabular}{|l|l|}
\hline \multicolumn{2}{|l|}{ ERIM REPORT SERIES RESEARCH IN MANAGEMENT } \\
\hline ERIM Report Series reference number & ERS-2001-43-ORG \\
\hline Publication & July 2001 \\
\hline Number of pages & 15 \\
\hline Email address corresponding author & turner@few.eur.nl \\
\hline Address & Erasmus Research Institute of Management (ERIM) \\
& Rotterdam School of Management / Faculteit Bedrijfskunde \\
& Erasmus Universiteit Rotterdam \\
& P.O.Box 1738 \\
& 3000 DR Rotterdam, The Netherlands \\
& Phone: +31 104081182 \\
& Fax: $\quad+31104089640$ \\
& Email: info@erim.eur.nl \\
& Internet: $\quad$ www.erim.eur.nl \\
\hline
\end{tabular}

Bibliographic data and classifications of all the ERIM reports are also available on the ERIM website: www.erim.eur.nl 


\title{
ERASMUS RESEARCH INSTITUTE OF MANAGEMENT
}

\author{
REPORT SERIES \\ RESEARCH IN MANAGEMENT
}

\begin{tabular}{|c|c|c|}
\hline \multicolumn{3}{|c|}{ BIBLIOGRAPHIC DATA AND CLASSIFICATIONS } \\
\hline Abstract & \multicolumn{2}{|c|}{$\begin{array}{l}\text { This paper attempts to develop concepts of project and contract organization to predict the } \\
\text { selection of contract type on infrastructure projects. Conventional wisdom is that at low risk fixed } \\
\text { price contracts are best, moving to remeasurement and then cost plus as risk increases. We } \\
\text { started trying to predict this from a transaction cost perspective, and such an analysis confirmed } \\
\text { conventional wisdom. However, it does not fit with current practice. Further, the differences in } \\
\text { transaction costs are small compared to differences in contract out-turn cost that occur under the } \\
\text { different motivational effects of different contract types. We therefore take a different perspective. } \\
\text { We assume the purpose behind a project contract is to create a cooperative project organization, } \\
\text { in which all participants, clients and contractors, are motivated to achieve common objectives, } \\
\text { their goals are aligned. This analysis confirms modern practice, and shows selection of contrac } \\
\text { type is related to uncertainty in the project's deliverables, and uncertainty in the process of their } \\
\text { delivery. Build only remeasurement contracts are used where uncertainty of both product and } \\
\text { process is low. Design and build fixed price contracts are used where uncertainty of the produc } \\
\text { is low, but the uncertainty in the process of delivery is high. Fixed price contracts should be used } \\
\text { where both are high. We extend the analysis to show when the client should be involved in the } \\
\text { project organization in an alliance contract, and when they should not, as in a traditional projec } \\
\text { contract. }\end{array}$} \\
\hline \multirow{3}{*}{$\begin{array}{l}\text { Library of Congress } \\
\text { Classification } \\
(\text { LCC) }\end{array}$} & $5001-6182$ & Business \\
\hline & $\begin{array}{l}5546-5548.6 \\
5548.7-5548.85\end{array}$ & $\begin{array}{l}\text { Office Organization and Management } \\
\text { Industrial Psychology }\end{array}$ \\
\hline & HD69.P75 & Project management \\
\hline \multirow{3}{*}{$\begin{array}{l}\text { Journal of Economic } \\
\text { Literature } \\
\text { (JEL) }\end{array}$} & M & Business Administration and Business Economics \\
\hline & $\begin{array}{l}\text { M } 10 \\
\text { L } 2\end{array}$ & $\begin{array}{l}\text { Business Administration: general } \\
\text { Firm Objectives, Organization and Behaviour }\end{array}$ \\
\hline & $\mathrm{L} 20$ & Firm objectives, Organization and Behaviour \\
\hline \multirow{3}{*}{$\begin{array}{l}\text { European Business Schools } \\
\text { Library Group } \\
\text { (EBSLG) }\end{array}$} & $85 \mathrm{~A}$ & Business General \\
\hline & $\begin{array}{l}100 \mathrm{~B} \\
240 \mathrm{~B}\end{array}$ & $\begin{array}{l}\text { Organization Theory (general) } \\
\text { Information Systems Management }\end{array}$ \\
\hline & $100 \mathrm{~B}$ & Organization theory \\
\hline \multicolumn{3}{|c|}{ Gemeenschappelijke Onderwerpsontsluiting (GOO) } \\
\hline \multirow[t]{3}{*}{ Classification GOO } & 85.00 & Bedrijfskunde, Organisatiekunde: algemeen \\
\hline & $\begin{array}{l}85.05 \\
85.08\end{array}$ & $\begin{array}{l}\text { Management organisatie: algemeen } \\
\text { Organisatiesociologie, organisatiepsychologie }\end{array}$ \\
\hline & 85.05 & Management organisatie: algemeen \\
\hline \multirow[t]{3}{*}{ Keywords GOO } & \multicolumn{2}{|c|}{ Bedrijfskunde / Bedrijfseconomie } \\
\hline & \multicolumn{2}{|c|}{ Organisatieleer, informatietechnologie, prestatiebeoordeling } \\
\hline & \multicolumn{2}{|c|}{ Projectmanagement, Contractmanagement, Organisatieleer, Transactiekosten } \\
\hline Free keywords & \multicolumn{2}{|c|}{ Contract type, contract selection, transaction costs, goal alignment, alliancing } \\
\hline
\end{tabular}




\title{
PROJECT CONTRACT MANAGEMENT AND A THEORY OF ORGANIZATION
}

\author{
By \\ Professor J Rodney Turner, Professor of Project Management \\ Dept of Marketing and Organization, Faculty of Economics, Erasmus University Rotterdam \\ Dr Stephen J Simister, Oxford Management and Research Limited
}

\author{
Institution Address \\ Address: Department of Business and Organization, Faculty of Economics \\ Erasmus University Rotterdam \\ Room H15-3, Burgemeester Oudlaan, 50 \\ 3062 PA Rotterdam, The Netherlands \\ Tel: $\quad+31-(0) 10-408-2723$ (Turner) \\ Fax: $\quad+31-(0) 10-408-9169$ \\ E-mail: $\quad$ turner@few.eur.nl
}

\section{Correspondence Address:}

Address: Professor J Rodney Turner Wildwood, Manor Close

East Horsley Surrey, KT24 6SA

Tel: $\quad+44-(0) 1483-282344$

Fax: $\quad+44-(0) 1483-284884$

E-mail: $\quad$ odneyturner@europrojex.com 


\title{
PROJECT CONTRACT MANAGEMENT AND A THEORY OF ORGANIZATION
}

Professor J Rodney Turner, Professor of Project Management

Dept of Marketing and Organization, Faculty of Economics, Erasmus University Rotterdam Dr Stephen J Simister, Oxford Management and Research Limited

\begin{abstract}
This paper attempts to develop concepts of project and contract organization to predict the selection of contract type on infrastructure projects. Conventional wisdom is that at low risk fixed price contracts are best, moving to remeasurement and then cost plus as risk increases. We started trying to predict this from a transaction cost perspective, and such an analysis confirmed conventional wisdom. However, it does not fit with current practice. Further, the differences in transaction costs are small compared to differences in contract out-turn cost that occur under the different motivational effects of different contract types. We therefore take a different perspective. We assume the purpose behind a project contract is to create a cooperative project organization, in which all participants, clients and contractors, are motivated to achieve common objectives, their goals are aligned. This analysis confirms modern practice, and shows selection of contract type is related to uncertainty in the project's deliverables, and uncertainty in the process of their delivery. Build only remeasurement contracts are used where uncertainty of both product and process is low. Design and build fixed price contracts are used where uncertainty of the product is low, but the uncertainty in the process of delivery is high. Fixed price contracts should be used where both are high. We extend the analysis to show when the client should be involved in the project organization in an alliance contract, and when they should not, as in a traditional project contract.
\end{abstract}




\section{INTRODUCTION}

During 2000, the authors ran a series of courses for the European Construction Institute, including ones on Contracts \& Procurement, and Partnering \& Alliancing. During these courses we were asked when fixed price, remeasurement or cost plus contracts should be used, and when alliancing contracts (which involve the owner in the project organization) should be used rather than traditional approaches (which do not). In response to the first question, we were only able to give the usual, glib answer that fixed price should be used when the risk is low, and cost plus when it is high. However, we were not able to answer the follow-up question of "Why?" There is recent research which showa when alliancing contracts should be used ${ }^{1}$. Perceived wisdom is that as risk increases on a project, the appropriate form of contract to govern the relationship between the client and contractor changes from fixed price, to remeasurement and finally to cost plus. But there is no real theory of project or contract organization that says why this should be so. Similarly there is no theory of when to involve the client in the project team and when not.

The authors set out with the intention of taking a transaction cost perspective to show how different contract types, as different governance structures, optimize governance costs associated with the different contract types in different risk scenarios. Turner and Keegan ${ }^{2}$ used a transaction cost perspective to analyze governance structures adopted by client and contractor organizations to manage the contractual relationship on projects. Williamson ${ }^{3}$ says that choice of appropriate governance structures for a contractual relationship is by definition a transaction cost issue. Thus, we thought it might be possible to bring a transaction cost perspective to bear on the selection of appropriate contracts types, and on whether to involve the owner or not. What this analysis suggested is transaction costs are not dependent on risk per se, but uncertainty in the definition of the project's product. At low levels of uncertainty, transactions costs associated with fixed price contracts are lowest, at intermediate levels those associated with remeasurement ones are lowest, and at high levels of uncertainty those associated with cost plus one are lowest, confirming perceived wisdom.

However, the role of transaction costs in determining project type is not supported by modern practice, and there is a fundamental flaw in the argument. The flaw is that if the project pricing terms are to be determined by the transaction costs, then out-turn cost of the contract works must be independent of the pricing structure. But different pricing structures motivate the contractor in different ways, so we expect out-turn costs to be different under different pricing structures. These differences are greater than the differences in transaction costs. Thus, the selection of appropriate contract pricing terms is determined by goal alignment, that is trying to get the contractor to share in the client's success from the project.

We therefore adopt an alternative view that the purpose of project organization is to create a cooperative system between client and contractors based on shared objectives. We show the selection of contract type is determined by uncertainty in the definition of the project's product and of the process to deliver it. At low levels of uncertainty of both, remeasurement contract's are appropriate. If the process is uncertain, but the product certain, fixed price design and build contracts are preferred. What the contractor has to deliver is clearly defined, but they take responsibility for finding the best work method for delivering it, and make profit from managing risk. If both product and process are uncertain, cost plus contracts, based on an alliance arrangement are preferred. The client and contractor work together to achieve the best outcome and share in any benefits that accrue. It also just happens that in selecting the appropriate contract to achieve goal alignment that transaction costs are minimized. 
In this paper we aim to contribute to a theory project organization and contract type selection, which is in an embryonic stage. We start by reviewing concepts selection of contract type in developing a project organization, and then definitions of different contract types by payment terms. We show how a transaction cost analysis predicts the conventional view of when the three types of contract should be used. However, we go on to point out the weaknesses in this analysis, and how its predictions do not conform to modern practice. We show how a need to obtain goal alignment and to avoid opportunistic behaviour lead to a better prediction of contract type selection. Finally we describe how alliance contracts are used to obtain goal alignment, but review when they should be used and when they should not.

Our analysis in this paper is mainly theoretical. However, to support our findings, we have done some field-work. We have interviewed people involved in major infrastructure projects, (Table 1). We have also drawn on research done by the Engineering Construction Institute ${ }^{1}$. Given our sources, our results mainly apply to infrastructure, engineering construction and heavy engineering, and not to information systems projects.

\section{CONCEPTS}

A contract is a way of creating a project organization. Levitt and $\mathrm{March}^{4}$ say:

The problem of organizing [is] seen as one of transforming a conflict (political) system into a cooperative (rational) one. A conflict system is one in which individuals have objectives that are not jointly consistent. It organizes through exchanges and other interactions between strategic actors. A cooperative system is one in which individuals act rationally in the name of a common objective.

Conflict systems can arise either through bounded rationality (the participants would like to act rationally but through human frailty fail to) or opportunism (the participants try to optimize their position at the expense of others). In order to reduce the chance of both of these happening, the client (who is ultimately responsible for creating the project organization and has the most to gain from its being effective) needs to:

- increase communication flow on the project to ensure participants have sufficient information to behave rationally, and to reduce the chance of the deceit on which opportunism depends

- ensure the project participants are properly incentivized so that all the project participants do indeed share a common objective

Appropriate governance structures (determined by the contractual relationships) need to be put in place to achieve these ends. Williamson ${ }^{3}$ says:

Transaction cost analysis [is] an examination of the comparative costs of planning, adapting, and monitoring task completion under alternative governance structures ... [so as to] align transactions (which differ in their attributes) with governance structures (which differ in their costs and competencies) in a discriminating (mainly transaction cost economizing) way.

In this paper we start by looking at the cost of planning, adapting and monitoring task completion under different contract payment terms. And then we look at how the different contract types create cooperative arrangements through goal alignment. But first we define what we mean by the different contract types. 


\section{DEFINITIONS}

For the purposes of this paper we assume there are five standard forms of project contract payment terms. Throughout the rest of the paper we talk about just three, fixed price, remeasurment and cost plus. However, there are three types of remeasurment contract. We illustrate the five types with the example of a property developer seeking a contractor to decorate offices in a new office block they are developing.

1. Cost-Plus: The contractor is repaid all their expenses, plus an agreed profit margin. The agreed profit margin can be a percentage of the out-turn cost, (cost plus percentage fee), or a fixed amount, (cost plus fixed fee). Whatever the contractor spends on painters and decorators, paint and wallpaper, is refunded, even if the unit rates are excessive and productivity rates are low.

2. Remeasurement based on a Schedule of Rates: The contractor is refunded their costs at agreed unit rates. The hours worked by painters and decorators, volume of paint and number of rolls of wall paper are measured, and the contractor paid an agreed amount per hour, litre and roll, even if the productivity levels are low.

3. Remeasurement based on a Bill of Quantities: The client pays a standard rate per metre squared of wall, based on agreed productivity rates and unit rates. The contractor will also want to claim for any delays caused by the client or other third parties.

4. Remeasurement based on a Bill of Materials: The client pays a standard rate per room, based on an average size of room, (or for a range of standard room sizes, one, two or three windows wide). This would be appropriate, as opposed to fixed price, if it was not known in advance how many of the rooms were going to be one, two or three windows wide. The contractor will again want to claim for delays.

5. Fixed Price: The contractor is paid a fixed-price, lump-sum, for the entire job. The client needs to specify in advance the exact number of rooms that are going to be one, two or three windows wide. If they underestimate the ratio of one window to three window offices, the contractor will benefit; if they overestimate, the contractor will claim.

There is not full agreement in the literature about these definitions, particularly what constitutes a remeasurment contract. The PMI ${ }^{\circledR}$ Guide to the PMBoK ${ }^{\circledR 5}$ defines only one type of remeasurment contract, that based on a Schedule of Rates. We think that most clients letting a cost-plus contract would specify maximum unit rates.

Conceptually all five contract payment terms should deliver the same out-turn cost. However, we suspect opportunism by the contractor will lead them to inflate claims for quantities used in the earlier types, and will lead them to create bogus claims for variations in the latter types. So how can we put in place control mechanisms to stop the opportunity for deceit, and what is the cost of those control mechanisms? And how can we align the client's and contractor's goals, so the contractor is rewarded for not indulging in opportunistic behaviour.

\section{COST OF MANAGING THE CONTRACT}

We consider first the transaction costs, that is the cost of planning, adapting and monitoring task completion, the cost of managing the contractual relationship. Cox and Thompson ${ }^{6}$ say: 
... there is an administrative process involved in contracting over an above the required actions of the contract. This process has costs attached to it which are referred to as transaction costs. Other transaction costs might include the identification, accreditation and selection of suppliers and/or performance monitoring and feedback.

Are these transaction costs related to the level of risk of the project? We assume the total cost to the client of a project is the out-turn cost of the contract, plus the transaction cost of settingup and administering the contract. The out-turn cost of setting-up and administering the contract has four elements:

1. the cost of specifying the product in the tender documentation

2. the cost of specifying the work methods (process) in the tender documentation

3. the cost of managing variations to the specification of the product during project delivery

4. the cost of managing variations in the specification of the process during project delivery

We said above that in a totally rational world, the out-turn cost of the contract should be the same under all five contract types. Thus the total cost of the project to the client will be determined by these four items, Figure 1, and so contract payment terms should be chosen which minimize them.

On fixed price contracts, the cost of all four will be low if the uncertainty of the product is low, that is the product is clearly understood, and the contractor takes responsibility for determining the best method of delivering it. This is especially so if the product can be specified in terms of cardinal points ${ }^{7}$, as was the case with the Øresund Link, and the tunnels and bridges on the Betuweroute Project. However, as uncertainty of the product increases, the cost of items 1, 3 and 4 will increase. More effort is need to specifying the product in the tender documentation, and the number and cost of processing variations will increase. The cost of processing variations will increase because the client will need to check the validity of the size of the claims made, challenge some of the claims made, determine the impact of changes on the cost and duration of other work. Indeed it is the last of these, the cost of item 4 above, which will be present on a fixed price contract and not on a cost-plus contract.

On a cost-plus contract, there is little effort in specifying the product or process in advance, (unless a target cost is desired). However, a process will be needed to monitor the costs of doing the work throughout the project. The same process will be needed regardless of the uncertainty of the product or process, and so the cost of administering the contract is independent of the risk. At low levels of uncertainty, this cost is higher than for a fixed price contract, but at high levels of uncertainty it will be less, especially as cost item 4 bites for a fixed price contract, (see Figure 1). The cost of a remeasurement contract will lie in between.

Thus we see that if considering the cost of administering the contract, the choice of governance structure is dependent on the uncertainty of the product, Figure 1. At low levels of uncertainty, fixed price contracts give lower administration costs; at high levels, cost plus contracts are best; and at intermediate levels, remeasurement ones are best. The choice does not depend on risk per se, and is independent of the uncertainty of the process. Indeed, the use of fixed price contracts for projects with uncertain process can encourage the contractor to find the best work methods independent of the owner. This can help achieve goal alignment as the contractor increases their profit while finding the best solution for the owner. 


\section{CRITIQUE OF THIS ANALYSIS}

There is a sweeping assumption in this analysis, and it does not match experience. The sweeping assumption is that out-turn cost of a contract is independent of the contract type. This we would not expect to be correct. Different contract types incentivize the contractor in different ways, and therefore we would expect their performance to be different under different payment terms. The transaction costs as identified are often fairly small compared to the out-turn cost of the project, and the differences between them under different terms of contract smaller still. Thus we would expect the payment terms to be chosen not to minimize the transaction costs, but to incentivize the contractors, as suggested by Levitt and $\mathrm{March}^{4}$.

This is borne out by evidence from the Betuweroute and Øresund Link Projects. Fixed price contracts are preferred when the uncertainty of the product is low, that is the project deliverables are clearly defined, (supporting the above analysis), but when uncertainty of the process is high. Remeasurement contracts are preferred when the uncertainty of both the product and process is low, which contradicts the above analysis, and conventional wisdom.

We should recall that we noted above that our three case studies, (Table 1), and other sources ${ }^{1}$, are from the infrastructure, engineering construction and heavy engineering industries, and so our results are limited to those industries. Recently, we presented a conference paper based on this work ${ }^{8}$. One delegate said in the information systems industry the transaction costs are much higher, and so in that industry would have as great an impact on the selection of appropriate governance structures for a project as would incentivization.

The reason fixed price contracts are preferred on the Betuweroute Project when the uncertainty of the process is high is that the contractor can then take responsibility for finding the best way of delivering the project, and can make extra profits from finding innovative solutions. Conventional wisdom is that it is unfair to ask the contractor to bear the risk arising from uncertainty of the process. However, one of our respondents said:

\section{The contract does not need to be fair, it just needs to be clear.}

Indeed, the contractor can make additional profits from managing the risk, as long as they understand it when they bid for the contract. The contractor buys the risk off the client and makes profits from managing it. Our respondent said that this was the only way that some of the work on the project could be done at prices the client could afford. Under this scenario, the four transaction costs identified above are all low. There are few set-up costs, and little need for the client to monitor the contractor's expenditure.

So why are remeasurement contracts used on Betuweroute Project for construction of most of the track foundation? The reason is that where it is unnecessary to involve the contractor at an early stage, the consultant has done the detail design before the contractors are appointed. The contractors undertake the work according to a standard schedule of rates specified by the Dutch Government. Indeed, the contracts are almost fixed price, with the price set by the client according to their schedule of rates, rather than being bid by the contractor, except if there are variations they will be made according to that standard schedule. Under this scenario set up costs are high. However, the detail design has to be done, whether it is done by the consultant or the contractor, so the set up costs are fairly independent of the pricing method adopted. Using a standard schedule of rates will also make the monitoring costs low. The client knows what the work should cost, and if it costs that there is no further discussion. 
A third type of contract type used on the Betuweroute Project is an alliance contract. This has been chosen for the construction of the foundation on one stretch of line where there is considerable uncertainty of both the product and the process and it is also thought that the client can make some contribution to resolving the problems. Along this stretch, the new line interferes with existing track, and there is a lot of cabling the location of which is not precisely known. There is also some resistance from local councils to give planning permission which is causing delays. Effectively a cost plus contract has been adopted, but this has been wrapped in an alliance to achieve goal alignment between client and contractors so they can work together to achieve an optimum outcome. Under this scenario the set up costs are low, but the monitoring costs are high. However, the monitoring costs are contained within the alliance, and are included in the normal project monitoring costs.

Thus, in all three cases, although the contract types are chosen to achieve goal alignment, they also do minimize transactions costs. Our respondent said that on the Beuweroute Project, the contract types were chosen according to two parameters, Figure 2:

- complexity of the situation

- the ability of the client to contribute to the resolution of problems

However, we think that the selection also conforms to two other parameters:

- uncertainty of the product

- uncertainty of the process

If the product is uncertain, then the client must be involved in the resolution of the problems.

There are to further points to note:

1. Figure 2 is the Goals and Methods Matrix developed by Turner and Cochrane ${ }^{9}$

2. in Figure 2 we have not suggested a contract type for the fourth quadrant, certain process/uncertain product. Information systems projects fall in this quadrant ${ }^{9}$, but we have already noted that they are beyond the scope of the study to date

\section{GOAL ALIGNMENT AND AVOIDING OPPORTUNISM}

Thus, the most significant issue to consider when choosing a governance structure for the contract is the need to achieve goal alignment between the client and contractor, and to reduce the chance and benefit for opportunism by the client or contractor. According to Levitt and $\mathrm{March}^{4}$, the purpose of project and contract organization is to create a cooperative system, and that is achieved by achieving common objectives by properly incentivizing the contractors. Turner ${ }^{10}$ shows that goal alignment comes from aligning the three Project Ps: process, product and purpose. The owner's profit comes from operating the product to achieve the purpose, the contractor's comes from undertaking the process to deliver the product. Lack of goal alignment will result in maladaptation of one or more of the three project Ps:

maladaptation of the process: the process does not deliver the product as designed maladaptation of the product: the product as designed does not meet the client's needs maladaptation of the purpose: the client's needs change from what was originally envisaged 
If the purpose, product and process are all defined, and unlikely to change, a remeasurement contract is the best approach. The client (or their consultant) do the detail design, and the contractor is awarded the work for build only, at a price defined by an agreed schedule of rates or bill of quantities, and which gives the contractor a reasonable profit. However, it this approach is unlikely to lead to improvement in the project's design or cost. The contractor is not going to suggest improvements unless they share the benefits. This just a lack of cooperation by the contractor, but the first priority of the contractor's directors is to their shareholders. They are absolutely required to maximize profits. It would be a dereliction of their duty to the shareholders to accept a remeasurement contract that did not allow them to share in cost reductions and then to suggest cost reductions. Clients need to recognize that. Often public sector clients out of a misguided sense of having to obtain the best value for tax payers, apply remeasurment contracts precisely, insisting any cost reductions are clawed back from contractors. This actually leads to the contracts being more expensive than they would be if the contractor were allowed to share in the improvements, and has happened on the Betuweroute project. Creating one-sided contracts leads to a conflict system, and increasing project costs. The contract does not have to be fair, just clear; but if it is clearly unfair, and the contractor is not left with the ability to manage risks to increase their profits, they will not share a common objective with the client. It must also be recognized that changes at this late stage are likely to lead to higher costs, not justified by any accruing benefits ${ }^{11}$.

If the product and purpose are fairly predictable, particularly if the product can be defined by cardinal points, then a fixed price contract can be the best way of ensuring the correct process is adopted. The contractor is made responsible for designing the best solution for delivering the project's product, and gains from any innovative solutions found. The client must not needlessly interfere in the contractor's work. One of our respondents said:

The client cannot be a control freak without taking a stick, and setting rules and regulations, and that will undermine the contractor's responsibility. The client will then be to blame for everything.

On the Øresund link, the client was there to help the contractors if they got into difficulty, but left them alone if that was what they wanted. On the other hand, on the Betuweroute Project the client has interfered in some design and build contracts and that has led to friction.

If the project's product is uncertain, or if the purpose may change through changing market conditions, then a cost plus contract based on an alliance may be best, (see below).

Finally, the client needs to put in place an information system to identify opportunism by the contractor at an early stage, without interfering or acting as a control freak. With fixed price, design and build contracts as used on the Øresund Link or Betuweroute Projects, that is not necessary, but it is necessary on remeasurement or cost-plus contracts, adding to the cost of their administration. However, on fixed price contracts where there is potential maladaptation of the product or purpose, it will be necessary to put in place a configuration management process to manage the refinement of the product ${ }^{2}$. That configuration management process will increase the administration costs and the potential cost of variations, leading to the undermining of the cost advantage of the fixed price contract as shown in Figure 1. 


\section{ALLIANCE CONTRACTS}

We saw in the previous section that alliance contracts can be useful where there is uncertainty in the product and process and the client has some knowledge of the situation to help the contractor directly to reduce the contract cost. If the client has no knowledge, it is best to leave the contractor to manage the problems on their own. In Partnering in Europe ${ }^{1}$, the ECI task force identify four criteria for adopting an alliance:

1. Owner business philosophy: The owner's approach to business performance will influence their desire to adopt partnering. Three stages of development are recognized, business as usual, continuous improvement or breakthrough performance. Only owners looking for breakthrough performance adopt partnering. This implies that this philosophy must be believed and operated at all levels in the owner organization. Gaining buy-in from the entire organization is key to making an alliance work, and is the first step in establishing a partnering arrangement ${ }^{1}$, but is beyond the scope of this paper. The Betuweroute Project took a different perspective. The owner was not so much looking to achieve levels of performance never before achieved, as to achieve things considered highly complex. It was felt the market had to solve the problems for the client. Where the client had no competence, fixed price design and build contracts were chosen, and the contractors left to solve the problems, as they were considered the best and most motivated. However, in the one case where the client had some competence, an alliance contract was adopted.

2. Project Size: The project has to be above a certain size to make the overhead of establishing the alliance, and transaction costs of maintaining it worthwhile. Projects below about \$US 150 million are not considered worthwhile.

3. Project risk and uncertainty: The project must involve risk in order for it to be worthwhile for the client and contractors to be able to share it. Alliances are powerful risk mitigating organizations, but the also create a cooperation system, by motivating both parties to reduce risk to share in the profits. Scott shows how the combination of business culture and risk leads to three different approaches to contracting, Figure 3.

4. Alliance partner availability and capability: The alliance partners must have the competence and financial backing to share the risk. To this the Betuweroute Project Client add the competence of the client. They must have the competence to contribute to the problem solving, otherwise they just get in the way and inhibit the contractor.

\section{CONCLUSIONS}

We started by trying to use transaction cost analysis to show when different contract pricing terms would be adopted. We demonstrated that this approach shows it is not risk per se which determines the appropriate type of contract, but uncertainty of the eventual product.

However, if we view the purpose of a contract is to create a project organization, and that should be based on a system of cooperation not conflict, then the need for goal alignment is more significant. This requires that all parties to a contract should be properly incentivized, and that is achieved by adopting contract pricing terms as suggested in Figure 2.

Appropriate channels of communication need to be maintained, and these are one of the main transaction costs in project contract management, and do seem to be minimized by adopting the appropriate pricing mechanism as suggested by Figure 2. Thus goal alignment is the main criterion of selecting contract pricing terms, but transaction costs are minimized en passant. 


\section{REFERENCES}

1. Scott, B, 2001, Partnering in Europe: Incentive Based Alliancing for Projects, Thomas Telford, London.

2. Turner, J R, and Keegan, A E, 2001, "Mechanisms of Governance in the Project-based Organization: a transaction cost perspective", European Management Journal, 19(3).

3. Williamson, O.E. (1996) The Mechanisms of Governance. Oxford University Press, New York.

4. Levitt, B, and March, J G, 1995, "Chester I Barnard and the Intelligence of Learning", in Organization Theory: from Chester Barnard to the Present and Beyond, ed O E Williamson, Oxford University Press, New York.

5. PMI, 2000, A Guide to the Project Management Body of Knowledge, $4^{\text {th }}$ edition, Project Management Institute, Sylva, NC.

6. Cox, A, and Thompson, I, 1998, Contracting for Business Success, Tomas Telford, London.

7. Kiely, D G, 1990, Defence Procurement: the Equipment Buying Process, Tri-Service Press, London.

8. Turner, J R, and Simister, S J, 2001, "Project contract management: a transaction cost perspective", in Proceedings of PMI Europe 2001, A Project Management Odyssey, London, ed T M Williams, Marlow Events, Marlow, UK, June.

9. Turner, J R, and Cochrane, R A, 1993, "The goals and methods matrix: coping with projects with ill-defined goals and/or methods of achieving them", International Journal of Project Management, 11(2).

10. Turner, J R, 1999, The Handbook of Project-based Management, $2^{\text {nd }}$ edition, McGrawHill, London.

11. Turner, J R, 2000, "Managing scope - configuration and work methods", in The Gower Handbook of Project Management, $3^{\text {rd }}$ edition, ed J R Turner and S J Simister, Gower, Aldershot.

\section{TABLES}

Table 1: Interviews conducted and projects analyzed

\section{FIGURES}

Figure 1: Relative cost of managing fixed price and cost-plus contracts at different levels of uncertainty of the product

Figure 2: Selection of contract types

Figure 3: Three contracting approaches 


\begin{tabular}{llll}
\hline Project & $\begin{array}{l}\text { Number/Type } \\
\text { of Contracts }\end{array}$ & Person Interviewd \\
\hline Nerefco Refinery & 1 & Alliance & Design and construction \\
& & & contractor's project manager \\
Øresund Link - fixed link & 3 & Fixed price design \& & Owner's contract manager on \\
Sweden-Denmark & & build & contract for immersed tunnel \\
Amsterdam North-South & 12 & Remeasurement & \\
Metro Link & & & \\
Betuweroute Civil Works - & 7 & Remeasurement & Manager of Waardse Alliantie, \\
high speed freight rail & 4 & D\&B FP & managing the alliance contract for \\
Rotterdam-Germany & 1 & Alliance & 23km of trach foundation \\
\hline
\end{tabular}

Table 1: Interviews conducted and projects analyzed 


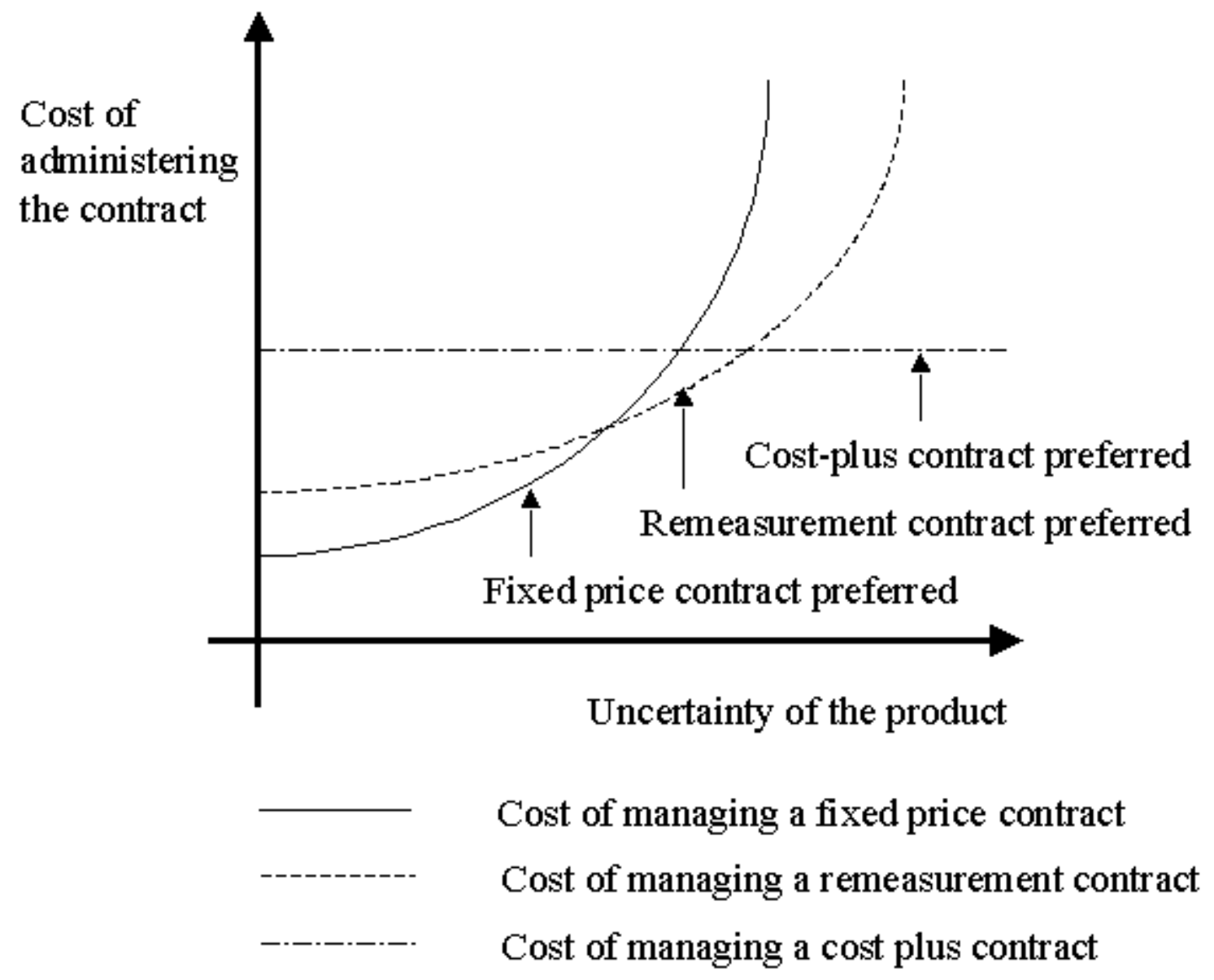

Figure 1: Relative cost of managing fixed price and cost-plus contracts at different levels of uncertainty of the product 


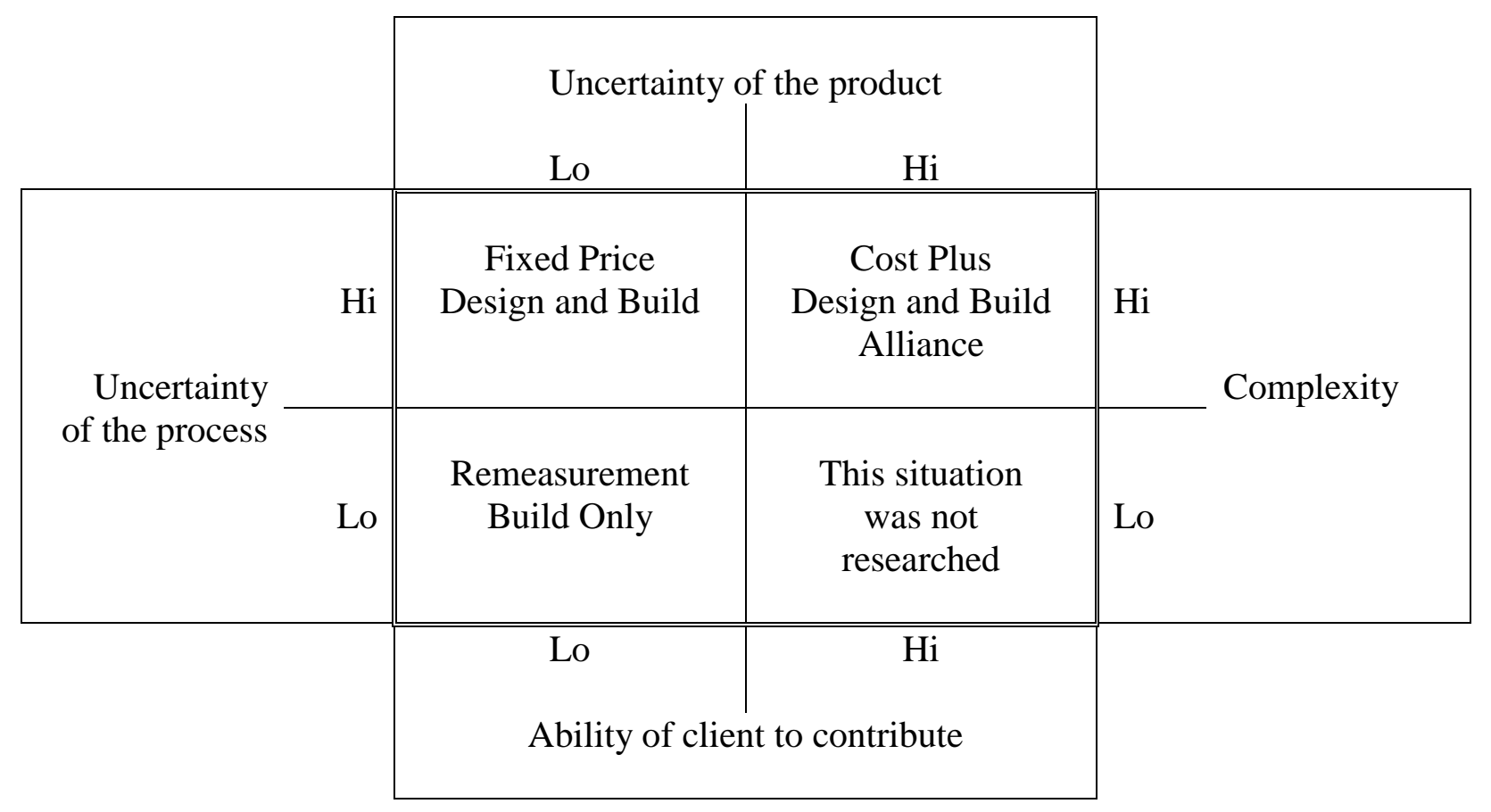

Figure 2: Selection of contract types 


\begin{tabular}{|c|c|c|c|}
\hline \multirow{2}{*}{$\begin{array}{l}\text { Business } \\
\text { Culture }\end{array}$} & $\begin{array}{l}\text { Trust } \\
\text { and } \\
\text { Mutual } \\
\text { respect }\end{array}$ & $\begin{array}{l}\text { Relational Contracts } \\
\text { High definition } \\
\text { Target sum bidding } \\
\text { Focus on efficiency }\end{array}$ & $\begin{array}{c}\text { Alliances } \\
\text { Goal allignment } \\
\text { Early involvement } \\
\text { Focus on Effectiveness }\end{array}$ \\
\hline & $\begin{array}{l}\text { Transaction } \\
\text { Based } \\
\text { and } \\
\text { Traditional }\end{array}$ & $\begin{array}{l}\text { Conventional } \\
\text { High Definition } \\
\text { Lump sum } \\
\text { Claim mentality }\end{array}$ & Get out \\
\hline & & Simple & Complex \\
\hline & & \multicolumn{2}{|c|}{ Business challenge } \\
\hline
\end{tabular}

Figure 3: Three contracting approaches 


\title{
Publications in the ERIM Report Series Research* in Management
}

\author{
ERIM Research Program: "Organizing for Performance"
}

\section{1}

Employee Perception on Commitment Oriented Work Systems: Effects onTrust and Perceived Job Security

Paul Boselie, Martijn Hesselink, Jaap Paauwe \& Ton van der Wiele

ERS-2001-02-ORG

The Emergence of a Private Business Sector in China: The Case of Zhejiang

Barbara Krug \& Hans Hendrischke

ERS-2001-03-ORG

Contingent Employment in the Netherlands

Ferrie Pot, Bas Koene \& Jaap Paauwe

ERS-2001-04-ORG

Under Construction. (Idendities, Communities and Visual Overkill)

Slawomir Magala

ERS-2001-17-ORG

The Dutch Banking Chipcard Game: Understanding a Battle between Two Standards

Henk J. de Vries \& George W.J. Hendrikse

ERS-2001-18-ORG

Empirical Evidence for the relation between customer satisfaction and business performance? Ton van der Wiele, Paul Boselie \& Martijn Hesselink

ERS-2001-32-ORG

On the emergence of growers' associations: self-selection versus market power

G.W.J. Hendrikse \& W.J.J. Bijman

ERS-2001-34-ORG

Employee perceptions of HRM and TQM and the effects on satisfaction and intention to leave Paul Boselie \& Ton van der Wiele

ERS-2001-42-ORG

Project Contract Management and a Theory of Organization

J. Rodney Turner

ERS-2001-43-ORG

2000

Critical Complexities, from marginal paradigms to learning networks

Slawomir Magala

ERS-2000-02-ORG

Marketing Cooperatives and Financial Structure: a Transaction Costs Economics Analysis George W.J. Hendrikse \& Cees P. Veerman

ERS-2000-09-ORG

* A complete overview of the ERIM Report Series Research in Management: $\underline{\mathrm{http}: / / \mathrm{www} . e r s . e r i m . e u r . n l}$

ERIM Research Programs:

LIS Business Processes, Logistics and Information Systems

ORG Organizing for Performance

MKT Marketing

F\&A Finance and Accounting

STR Strategy and Entrepreneurship 
A Marketing Co-operative as a System of Attributes: A case study of VTN/The Greenery International BV, Jos Bijman, George Hendrikse \& Cees Veerman

ERS-2000-10-ORG

Marketing Co-operatives: An Incomplete Contracting Perspective

George W.J. Hendrikse \& Cees P. Veer man

ERS-2000-13- ORG

Ownership Structure in Agrifood Chains: The Marketing Cooperative

George W.J. Hendrikse \& W.J.J. (Jos) Bijman

ERS-2000-15-ORG

Organizational Change and Vested Interests

George W.J. Hendrikse

ERS-2000-17-ORG

Is Polder-Type Governance Good for You? Laissez-Faire Intervention, Wage Restraint, And Dutch Steel Hans Schenk

ERS-2000-28-ORG

Foundations of a Theory of Social Forms

László Pólos, Michael T. Hannan \& Glenn R. Carroll

ERS-2000-29-ORG

Reasoning with partial Knowledge

László Pólos \& Michael T. Hannan

ERS-2000-30-ORG

The Strawberry Growth Underneath the Nettle: The Emergence of Entrepreneurs in China

Barbara Krug \& Lászlo Pólós

ERS-2000-34-ORG

Trading Virtual Legacies

Slawomir Magala

ERS-2000-36-ORG

The Interdependence between Political and Economic Entrepeneurship

Barbara Krug

ERS-2000-43-ORG

Ties that bind: The Emergence of Entrepreneurs in China

Barbara Krug

ERS-2000-44-ORG

Human Resource Management and Performance: Lessons from the Netherlands

Paul Boselie, Jaap Paauwe \& Paul Jansen

ERS-2000-46-ORG

Possible futures for the HR function in different market

Roger Williams, Jaap Paauwe \& Anne Keegan

ERS-2000-54-ORG

Quantity versus Quality in Project Based Learning Practices

Anne Keegan \& J. Rodney Turner

ERS-2000-55-ORG

The Management of Innovation in Project Based Firms

Anne Keegan and J. Rodney Turner

ERS-2000-57-ORG 
Learning by Experience in the Project-Based Organization J. Rodney Turner, Anne Keegan \& Lynn Crawford ERS-2000-58-ORG 